DOI: $\underline{\text { https://doi.org/10.31933/dijemss.v2i4 }}$

Received: $30^{\text {h }}$ March 2021, Revised: $15^{\text {th }}$ April 2021, Publish: $25^{\text {th }}$ April 2021

\begin{tabular}{|c|c|c|}
\hline PUNASTIST & $\begin{array}{l}\text { DIJEMSS } \\
\text { DINASTI INTERNATIONAL JOURNAL } \\
\text { OF EDUCATION MANAGEMENT AND } \\
\text { SOCIAL SCIENCE }\end{array}$ & $\begin{array}{r}\text { https://dinastipub.org/DIJEMSS } \\
\text { editor@dinastipub.org } \\
08117401455\end{array}$ \\
\hline
\end{tabular}

\title{
LOOKING FOR THE FORM OF INDONESIAN DEMOCRACY: STUDY OF PANCASILA IDEOLOGY TOWARDS CONCURRENT ELECTIONS IN 2024
}

\author{
Osbin Samosir \\ Lecturer in Political Science at FISIPOL, Christian University of Indonesia, Jakarta, \\ osamosir@gmail.com
}

Corresponding Author: First Author

\begin{abstract}
Indonesia's democracy has taken huge leaps since the starting of reformation in 1998, compared to Soeharto's authoritarian ruling (New Order) from 1966 to May 21, 1998, and during Soekarno's ruling from the country's independence in 1945 until 1966. One year after Soeharto's fall on May 21, 1998, Indonesia held its first democratically election on June 7, 1999. The election was contested by 48 political parties. In 2004 , Indonesia for the first time held its direct presidential election. One year later, Indonesia held its first regional elections, where voters directly elect governors, regents and mayors. The question is on whether the current democratic practices have been in accordance with all democratic values as intended by Pancasila ideology as the basic foundation for Indonesia in all political actions? Pancasila: 1). The belief in one God, 2). Just and civilized humanity, 3). Indonesian unity, 4. Democracy under the wise guidance of representative consultation, 5). Social justice for all peoples of Indonesia. The country's founding fathers formulated the understanding of democracy based the traditional practices of democracy at the grassroots level which have lasted for centuries throughout the country. However what happens now is that Indonesia just imitated the posture of Western/European democracy. It turns out that Indonesian democracy is very fragile because it does not have a tradition of democracy that grows independently from Indonesia's fertile soil itself, but democracy is taken from other cultures that have grown and developed in Europe and then transplanted in Indonesian soil. Therefore, the format for direct elections in Indonesia must be reviewed for improvement.
\end{abstract}

Keywords: Pancasila, ideology, democracy, general election

\section{INTRODUCTION}

State ideology Pancasila is often not considered vital as the foundation of Indonesian state. Public enthusiasm for Pancasila has been much less meaningful compared to the enthusiasm of the participants of the Indonesian Independence Preparatory Investigation 
Agency (BPUPKI) on June 1, 1945, in Jakarta, when Bung Karno in his historic speech, proposed Pancasila as the foundation of the state and the outlook on life (Welthanschauung) for an independent Indonesia. The forum participants accepted the proposal by acclamation after his speech received many applauses for respect and approval (Kleden, 2019).

The problem is, the democracy initiated by Soekarno in 1945 is said to have originated from the democratic tradition found in villages throughout the archipelago. Meanwhile, democracy that is currently practiced in Indonesia is democracy like that which is growing in Europe / West and the United States. Is democracy as understood in Europe the same as democracy that developed in the Indonesian archipelago over the previous centuries, which was carried out since the era of the Indonesian Reformation in 1998 until now? At least the first two presidents of Indonesia, namely President Soekarno served for a period of 21 years (1945-1966) and President Soeharto who served for a period of 32 years (1966-1998) actually showed that the character of the royal model who wanted to rule as long as possible became very clear.

So the great difficulties of Indonesian democracy remain today since the Reformation Era began in 1998. Indeed, the format of general elections from 1999 to the 2020 General Election shows that the practice of democracy that is promoted is the practice of a modern democratic pattern with direct elections on the principle of one-person, one-vote, one-value (opovov) with an open proportional system. In fact, democratic traditions such as modern elections have never occurred in villages across the archipelago.

The question is on whether Indonesia's democracy in the last 22 years (1998-2020) has been in accordance with the spirit of democracy as contained in the Pancasila ideology? How is the meaning of democracy in Pancasila in relation with the practice of oriental culture in Indonesia's unique democracy?

This paper uses a qualitative research methodology, namely literature search and indepth discussion. The main literature was taken from the views of the Founding Fathers: Soekarno, Moh Hatta, Soepomo, and Muh Yamin when they initiated Pancasila in the BPUPKI and PPKI sessions. Then the state documents discussing Pancasila. This paper uses the democratic understanding of Robert Dahl, Samuel Huntington, Franz Magnis-suseno and Miriam Budiarjdo. In-depth discussions were held with Pancasila thinker Ignas Kleden (a sociologist and thinker of Indonesian nationality) and Maswadi Rauf (professor of Political Science at the University of Indonesia).

\section{PANCASILA AS IDEOLOGY}

The status of Pancasila as the state ideology was formulated by Soekarno. Pancasila becomes a philosophical grondslag, a philosophical foundation for all of free Indonesian citizens. Apart from being an ideology, Pancasila also becomes a Weltanschuung or world view of the world that determines the way of life (Soekarno, 1945). Pancasila as an ideology is a theory about the form and duties of the state such as Staatsphilosophie, while as Weltanschauung, Pancasila is the guideline for people in their attitude and conduct toward the state and other people in the society. Bung Karno conveyed his mature thoughts like Thomas Jefferson when writing the manuscript of the Declaration of Independence for the US, or Dr. Sun Yat Sen when writing his ideas San Min Chu I or the three principles of independent China (Mintsu /nationalism, Minchuan /democracy, and Min Sheng/socialism).

Seen from the current retrospect, the five Pancasila principles took into account national and international context at that time. For example, Indonesian society has deep 
religious feelings. Especially in national politics, Islam is the religion of the majority, which clearly would have difficulty in joining and supporting Indonesia as a new state when The Belief in One God principle was not included as a principle in the state foundation. There was certainty in Indonesian society that the new country to be established would not a secular state.

Humanity is a required principle by all democratic countries in the world, and human right is an issue that gets an increasing international attention. After all, local intelligentsia would demand human dignity be given a place in the state basis. It must be ensured that the state to be established respects human dignity and human right. Apart from that, Nationhood was a principal matter for major political party at that time, the Soekarno- founded Indonesian National Party (PNI). Without the principle of nationhood, the party members would face difficulties in supporting the new independent state.

Bung Karno definitely understood very well that nation- state idea was an emerging phenomenon in world politics in the 19th century in the Western world, and immediately got an echo in the independence struggles in the third world in the 20th century. The same way of thinking applied to Democracy or Populism as as a principle that was adopted by all newly independent states to measure how far a country got rid from the ancient regime that stood on feudalism, colonialism and imperialism. Independence means the freedom of a nation from being submissive to foreign powers that do not respect the dignity of the colonialized people as human beings.

Social Justice principle is included in Pancasila because in political context at that time, there were still quite many leftists under the leadership of Tan Malaka and other figures. Leftist politics strongly opposed the existence of social classes which formation was based on production relations. There is a ruling class that controls production and there is a class of workers who is exploited by the capitalist class (Soekarno, 1964). The proletariat are those who do not have the means of production and merely rely on the the payment they received as physical laborers from the capital owner (Soekarno, 1978). Meanwhile, the Marhaens, according to Bung Karno's explanation, are those who do not sell their physical labor to capital owners, but have their own means of production (Dahm, 1987).

\section{DEBATE ON THE STATE FORM: KINGDOM VS DEMOCRATIC SYSTEM}

How is the content of democracy understood in Pancasila? There were serious debates among the Founding Fathers of the Nation on whether Indonesia actually has its own democratic tradition so that it is appropriate to choose a democratic government system such as America or Europe, or in fact Indonesia's political tradition adopts a kingdom system. Long debates took place during the formulation of state formation whether a democratic/republic or kingdom system.

The debate ended with voting because some wanted kingdom state and others wanted republic. The BPUPKI meeting on July 10, 1945 at the Pejambon Building ended with a vote. There were 64 participants, 55 participants chose the republic state system, while those who preferred kingdom were 6 participants, and 3 other votes were declared void.

\section{a. Arguments of The Kingdom System}

The existence of kingdom system in the archipelago was revealed by Muh Yamin on May 29, 1945. At that time Yamin said that there were about 300 local kingdoms in Indonesia. However among all regional kingdoms at that time there was not a single regional kingdom 
capable of forming a nation state (état national), almost all of them were inheritance-state patterns (états patri-moines), and perhaps one or two kingdoms were still a state of power. (états puissances). The 300 regional kingdoms could not be used as material for the formation of a kingdom state.

Susanto Tirtoprodjo, one of the Founding Fathers of the Nation, at the BPUPKI meeting on July 10, 1945, emphasized that the suitable state form for Indonesia was kingdom system (Susanto, 1945). According to Susanto, villagers and people at the grassroot levels only understood kingdom system but they have difficulties in choosing their king(1945). When only one local king to be elected as king at that time, there would be no acceptable king by all people.

When the newly appointed king was not the current king, people would probably accept him as the country's leader, but not yet as a king. So Susanto proposed that the head of stateto be elected within a certain period of time, and the state was not called a republic. At a certain time, because the elected Head of State was a very modest figure and beloved by people, the head of the country could be crowned as king in the future. "As I have stated in the draft of the Constitution, the Head of State is elected for a certain period of time, but when the Head of State was meritorious and loved by the people, he could be crowned as a king. So this is my basic view about the form of the state," said Susanto.

Pieter Frederik Dahler, one of the participants of the BPUPKI Session on July 10, 1945, also gave an overview of the kingdom system in Indonesia. Dahler said, when someone asked him why he (in1945) proposed monarchical state system, then he would reply that he was thinking about the proverb or remarks in an oriental philosophy which said that kingdom form is indeed a feature of human progress, religious progress, and the progress of everything in this world, because the king always becomes God's representative in the world.

Dahler followed the words in the Western language that king is accompanied by several titles for example: Bij de genade Gods. "I utter these words while thinking about the condition of Indonesian nation in general, the state of mind and religion of Indonesian people which are still firmly connected to old customs thatHestill exist and live in the heart of the Indonesian people," said Dahler at that time.

He argued that the suitable state character for Indonesia is kingdom. By quoting the holy Koran in the Surah Al-an'am, according to Sanusi king in the monarchical state system has become the absolute representative of God. Therefore, the king must be a very holy person, even a hundred times holy compared to others. A person who will be appointed as king may not think about himself or his relatives or his family, but must think about the interests of the wider community. With this holiness, the country must be resurrected and awakened by choosing the king as Head of State.

\section{b. Democratic System Argument}

The supporters of democracy in the BPUPKI meetings in 1945 argued that Indonesia already had a democratic tradition in local culture. Mohammad Hatta strongly believed that democracy in Indonesia has taken root in the social life of Indonesian rural communities so that democracy cannot be eliminated. According to Hatta, "... social analysis shows that true Indonesian democracy remains strong despite feudalism, because land as the most important production factor belongs to the village community, does not belong to king. And social history in the West has shown that in the era of feudalism, land ownership is the basis of 
freedom and power. Those who lose their rights to land, lose their independence "(Hatta, 1945).

Mr Muhammad Yamin's speech on May 29, 1945, insisted that the content of democracy was already in accordance with the culture and religion that had grown in Indonesia for thousands of years, namely the religion of Islam: “... Mutual delibration has been carried out as best as possible, therefore by implementing this basis, all ummah (people) or their representatives can participate in the formulation and implementation of the state."

Muh Yamin firmly believed that since ancient times long before Islam developed, there was already village structure, community structure, and land rights structure in Indonesia that relied on a collective decision called mutual unanimity over the society. The basis of this unanimity is as old as the structure of the village, nagari (semi autonomous region), clan and others, and this consensus previously eliminated individual basis and raise co-existence in an orderly society and in a village state system, which was maintained for the common interest of the people for generations. The basis for consensus did not collapse because of the influence of Buddhism or Hinduism, until the 16th century, when Madjapahit Empire collapsed.

He pointed out that Indonesian democracy was extracted from the spiritual spirit of Indonesian nation itself, meaning that the state did not unite itself with the largest group in society, nor did it unite itself with the strongest political or economic groups, but united itself with the whole society. So the basis of individualism, the system of Western democratic parliamentarism, must be rejected. So the State of Indonesia government must form a system of consultative bodies (Risalah Sidang, 1945).

Soekarno, the initiator of Pancasila in his speech on June 1, 1945, recognized as the birthday of Pancasila, emphasized the principles of Indonesian democracy, namely: "... a lifegiving society, namely the politiek- economische democratie which is capable of bringing about social welfare! [...] meaning the best possible mutual welfare. " (Risalah Sidang, 1945).

The 1945 debate over the form of kingdom state or republic, proved there were 300 kingdoms in Indonesian rural areas until 1945. However, because democracy system developed in civilized world culture at that time, republic form became the choice of the majority of founding fathers, most of whom once studied in Europe.

How has democracy been practiced in Indonesia since the Reformation Era in 1999, especially toward the 2024 General Elections?

\section{PRACTICE OF DEMOCRACY IN POST REFORMATION INDONESIA}

The current democracy practice in Indonesia is not different from other parts of the world, namely: 1) control over government decisions, through citizens' presence in supervising policies taken by state officials and institutions; 2) thorough and fair general election process in the context of involving all people in election; 3) the right to vote and to be elected for all eligible citizens; 4) freedom of expression which is free from intimidation; 5) freedom of access to information needed by the public; 6) freedom of association for citizens without any pressure and exceptions (Dahl, 1971). George Sorensen saw that the path "to democracy" is not a simple, single, and linear path, but there are at least three generic political dimensions of democracy, namely "competition, participation, and civil and political freedom" (Sorensen, 1993).

All criterias from Dahl and Sorensen above are principles that have also been implemented in Indonesia since the fall of the authoritarian New Order government in 1998. The Reformation era has conducted three types of direct general elections by the people, 
namely: Legislative elections (for the House of Representatives at national level and Regional Legislative Council) direct presidential election, and Regional Head elections (governors, mayors, regents), something that the authoritarian New Order regime never did in the past.

\section{a. Indonesian Legislative Elections}

Indonesian legislative elections in the early days of the Reformation Era in 1999 were very dominant, making the legislative power very powerful (legislative-heavy). During the New Order Era there were only three election participants, namely: the United Development Party (PPP), the Functionary Group (Golkar), and the Indonesian Democratic Party (PDI), and was always won by Golkar Party in six general elections. (1971, 1977, 1982, 1987, 1992, 1997) by more than $80 \%$. In the Reformation Era, legislative elections were contested by multi parties in the 1999, 2004, 2009, 2014 and 2019 elections. In the 1999 Election, 48 political parties participated, from 141 political parties registered at the Ministry of Law and Human Rights of the Republic of Indonesia. Among them, 18 political parties obtained seats in Parliament, a very large number.

It was not very different in the 2004 General Election with a total of 24 political parties participating and 16 of them won seats in the Parliament. Multi-party system always takes place in post 2004 elections. The authoritarian New Order government used closed proportional system, where only candidates in the top ranks had the chance to get seat in the legislature after going through a special investigation by President Soeharto's government, and Golkar Party which should be the winner of elections.

Since 2004, legislative elections uses open proportional system. The peak open proportional system started in the 2009 Election, where the party's task is only to propose legislative candidates, and election winner among the candidates is largely determined by the number of votes they won. As long as the candidate's votes are the highest among the candidates, then the party seat quota will be automatically obtained by the candidates who won most votes, regardless of his/her rank in the official list.

At least two of the applied legislative electoral systems that have occurred since the Reformation Era reflect the realization of the modern democracy principles as initiated by democracy thinkers such as Robert Dahl, Samuel Huntington, Lucian Pye, Franz Magnissuseno, Miriam Budiardjo, and others. This means that the above democratic principles do not originate from indigenous and local cultures that have grown up in Indonesia for centuries, which are then nurtured, because they are in accordance with the principles of modern democracy, but new principles that are embedded later in Indonesian democracy with modern formats that apply across the world.

Indonesia began to adopt direct presidential election in 2004. It is a big leap in the development of Indonesian democracy. It is a total contrast to the Old Order era during the 21 years of President Soekarno's administration. Soekarno was appointed by the BPUPKI on August 18, 1945 and he ruled Indonesia until 1966. In the course of history, President Soekarno created Guided Democracy in 1959, and appointed himself as the President of Indonesia for Life. The country's political situation was very unstable during the Old Order era with the rises and falls of a number of prime ministers. President Soekarno fell down after the fail coup of the Indonesian Communist Party (PKI) on September 30, 1965, and was followed by massive student demonstrations in 1966.

Previously, what was far worse in true democracy was the authoritarian government of President Soeharto, which ruled Indonesia from 1966 to 1998, in which elections were merely 
a formality for the People's Consultative Assembly (MPR) to reelect Soeharto as the only candidate for the elections.There was a stereotype at that time, only an experienced President was eligible to become the next presidential candidate, and became the logic that was built by the New Order government so that President Soeharto was the only candidate for President in 1977, 1982, 1987, 1992, and 1997 elections.

\section{b. Presidential Elections 2004-2019}

In the Reformation Era, a major leap in democracy has taken place, where people have the right to directly elect president and vice president since 2004. In addition, the five-year term of office of the president is limited to a maximum of two periods so that each president has a maximum tenure of ten years. It is an effort to prevent the repetition of what happened in the past, when the country was too long in the hands of a president, as what happened during the era of Soekarno and Soeharto.

As the result of the direct presidential election and the term restriction, President Susilo Bambang served the country for two periods from 2004 to 2014. His successor, President Joko Widodo also can only main his position for another five years after he won the presidential election again in 2019. In the 2024 presidential election, Indonesia voters will elect a new president. Of course this direct presidential election system has been used much earlier by democratic countries in Western countries such as in the United States, United Kingdom with its parliamentary system, in France with its semi presidential system, and in almost all European countries which adhere to mature democracy system.

So if we refer to the history of Indonesia, where leadership used kingdom system in the past in the region, the position of king was passed down from generation to generation and was not elected. The most concrete examples are still found in a number of areas of the archipelago such as the Sultanate of Yogyakarta who is now is led by Sultan Hamengkubuwono X. The same thing has happened in the Surakarta Sultanate from 1705 until now. The city is now led by Pakubowono XIII. It also happens in the Sultanate of Cirebon and a number of regions that still recognize kingdom system. The two kingdoms that were best known to the public in the past were the Sriwijaya Kingdom which expanded its territtory up to India and the Majapahit Empire. The power of kingdom system slowly disappeared after Indonesia's independence on August 17, 1945.

If you look at what had been done by President Soekarno during his 21-year reign and President Soeharto in his 32-year ruling, it can be said that both of them had named themselves as life-time king, and did not want to be replaced by other people, exactly the character of a king. The change in leadership could only happen after massive people's power movement, especially students and youths, who forced the two leaders to resign. Therefore it is evident that Indonesia does not have a history of democracy in presidential election. Soekarno claimed there was already democracy in villages in his speech on June 1, 1955, when he said Indonesian democratic system must be rooted in democracy value that has grown in villages throughout Indonesia for centuries. In our opinion, this claim however does not have roots.

According to the study of this paper, democratic system in Indonesia, as intended and understood by democratic system in the West that prioritizes equality of human rights and the authority of citizens to freely express their views and opinions as pointed by by Robert Dahl above, never exists. The format of democracy that is currently being initiated in the Indonesian presidential election system is an electoral system, as happened throughout Europe and the 
United States. Due to the same demands, the direct presidential election system was implemented in Indonesia.

\section{c. Direct Regional Head Election}

A new and very interesting phenomenon of democracy system in Indonesia is the people's right not just to directly elect their president, but at regional level, people now also have the right to directly elect governor, regent and mayor. This direct regional election process began in 2005, a year after the 2004 direct presidential election.

Local elections were held in provinces, regencies and cities when the five-year term of governor, regent and mayor expired. This regional election system was applied for 9 years until 2014. This system was slightly changed in 2015, where elections were organized simultaneously in 2015, 2017, 2018, and 2020.

Regional head elections were held simultaneously throughout Indonesia on the same day and hour in provinces, regencies and cities who leaders' term would expire soon. The main essence of direct election system for regional heads is provide full freedom for the people to exercise their constitutional rights to elect whoever candidates they want.

So the main task of candidates is to win the trust of voters in the democratic competition. Candidates who are most able to draw sympathy from the community will win the election. And vice versa, voters are free to choose the candidates for regional head who have proved their track record and they belive as the most suitable and appropriate person to lead their regions for five years. Social punishment is also very possible given to incumbent regional heads who failed to delivere their promise to the civil society, by voting other candidate.

This process greatly fosters democracy in civil society because it is inversely proportional compared to New Order-32 year ruling. At that time central government had the final say on who would be governors, mayors or regents, and the election by the Regional Legislative Council (DPRD) was just for formality.

At that time, legislature members in all regions throughout Indonesia were dominated by the Golkar Party so that all governors and regents or mayors came from the choices of the central government. People have no right to choose their leader. The current regional head election system has also been practiced much earlier by democratic countries in the world such as U.S., United Kingdom, France and Australia. Indonesian history shows that from the National Awakening Era from 1908 until 2004, all regional heads were based on appointment and not through democratic elections.

During New Order's ruling, Soeharto acted like a king in appointing regional leaders from the State Palace.

\section{CONCLUSION AND EVALUATION Conclusion}

The democratic content in Pancasila, as intended by the nation's founders such as Soekarno, Moh Hatta, Moh Yamin, Prof. Soepomo and others, was actually the content of democracy which was understood by all civilized nations at that time throughout the world. This means that the content of democracy in Pancasila actually follows the notion of democracy in general, not pre-existing traditions. It is evident that the proposed form of a royal state as a form of indigenous local government system in Indonesia has for centuries still received the support of a significant number of votes who want a country to be a kingdom. 
But the victory of the democratic system initiated by Indonesian intellectual and educated sages who had learned from Europe or at least studied how the development of world history and world democracy resulted in Indonesia deciding to adopt a democratic system as understood by the civilized nations of the world. This means that Indonesia does not have the tradition and history of democracy as understood by modern democracy, as evidenced by the practices of the government system that occurred during the Old Order of President Soekarno (21 years) and the New Order of President Soeharto (32 years) always trying to direct itself to a non-governmental system. democratic.

Direct election system as modern form of democratic format that prioritizes human rights was adopted from Western principles. Direct election system, both legislative and direct presidential election since 2004, and direct election of regional heads since 2005, is an illustration of the European democratic format, adopted in the Reformation Era. It was a separate pattern from a situation that had never happened before, both before our independence in villages throughout the country, as well as during the Government of President Soekarno in the Old Order and the government of President Soeharto in the New Order era. So Indonesian democracy is a Western-style democracy that is tried to be integrated and attached to become the idea of democracy in Indonesia.

Will Indonesian democracy succeed? Seeing the historical facts that the birth of the 1998 Reform Era has been 22 years until 2020, Indonesia's democracy is still stumbling. Toward the 2024 simultaneous elections, the government needs to review Indonesia's direct election system which has generated many problems and difficulties. Indonesia should focus more on the spirit of founding fathers to re-function the people's representatives to elect the president, governors, regents and mayors. Of course it should be openly and democratically conducted and public participation remains dominat like what happens now.

\section{Evaluation}

Democracy is the right choice because it respects human dignity as a top priority. Our challenge is how to ground the basic values of democracy to become the soul and mentality of the entire Indonesian people. We must continue to strive for a long journey of searching for the most appropriate democracy figure for Indonesia, a democracy that will never stop until one day we are proud of our Indonesian democracy.

The biggest challenge, of course, is that it is impossible for us to go back to the national kingdom format, let alone the regional system kingdom format. The political practices carried out by the first two presidents of Indonesia were characterized by "kingdoms" because they practiced themselves as masters (kings) and not servants (democracy). President Soekarno has ruled for 21 years, which is a very long age of rule and is contrary to modern democracy. The same power as President Soeharto, who ruled for 32 years, whose government was very authoritarian and hegemonic, characterized him as a feared king.

For responding to this paper, there is a need for further writing to assess how high quality or how bad the values of democracy actually run in principles of Indonesian democracy. Will it last for a long time to grow better, or should it look for another form of democracy. Or, in fact, the democratic format is not suitable for the Indonesian context, which from the beginning did not have a democratic tradition but an undemocratic royal tradition in particular. The next article is eagerly awaited to answer this conclusion or to continue the possible format of democracy that needs to be initiated in Indonesia. 


\section{BIBLIOGRAPHY}

Alam, Wawan Tunggul. Sukarno vs. Hatta. Jakarta: Gramedia Pustaka Utama, 2003.

Almond, Gabriel A., "Socialization, Culture and Political Participation", in Mohtar Mas'oed and Colin MacAndrews (eds.), Comparison of Political Systems, Yogyakarta: Gadjah Mada University Press, 2000,

, Gabriel A. and G. Bigham Powell, Jr. Comparative Politics, System, Process and Policy, second edition, Boston: Little, Brown and Company, 1978

Anderson, Benedict and Audrey Kahin (eds). Interpreting Indonesia Politics: Thirteen Contributions to the Debate. Cornell Modern Indonesia Project, Ithaca, New York, 1982.

Brown, Bernard E. and Roy C. Macridis, eds. Comparative Politics: Notes and Readings, 8th edition. Belmont: Wadsworth Publishing Company, 1996.

Budiardjo, Miriam. Basics of Political Science. Jakarta: Publisher PT Gramedia Pustaka Utama, 1993. , Miriam, Democracy in Indonesia: Parliamentary Democracy and Pancasila Democracy (Collection of Writings). Jakarta: PT Gramedia Pustaka Utama, 1990.

, Miriam (ed.). Symposium on Capitalism, Socialism, Democracy. Jakarta: Publisher PT Gramedia, 1984.

Burns, Edward McNall, et al. Western Civilization: Their History and Their Culture. New York: W.W. Norton \& Company, 1984.

Dahl, Robert A. Democrcy and Its Critics. New Haven: Yale University Press, 1989.

, Robert A. On Democracy. New Haven: Yale University Press, 1989

Dahm, Bernard. Sukarno and the Independence Struggle. Jakarta: LP3ES, 1987.

Emil Salim, "Democracy in Indonesia moving from stagnation to regression" in thejakartapost.com, Monday, September 28, 2020.

Feith, Herbert. The Decline of Constitutional Democracy in Indonesia. Ithaca and London, Cornell University Press, 1962.

Fuqoha and Sukendar, "Dynamics of Islamic Social and Political Movement in the 2019 Indonesian Presidential Election" in the Proceedings of the National Conference of Administrative Sciences. Bandung: STIA LAN Bandung, October 2018.

Hatta, Mohammad. Collection of Essays (I). Publisher of "Bulan Bintang", Jakarta, 1952.

, Mohammad, "Pendjadjahan and National Problems", Daulat Ra'jat No. 11, 30 December 1931.

, Mohammad, "Indonesia In Perhoeboengan Doenia", Daulat Ra'jat No. 40, 20 October 1932.

, Mohammad, "Collectivisme Toea and Baroe", Daulat Ra'yat No. 75, 10 October 1933.

Center for Political Studies (Puskapol) UI. The results of the Asian Democracy Index Research: The Case of Indonesia in 2014. UI Postgraduate, Jl Salemba Raya, Central Jakarta, Friday (12/12/2014).

Collection of Minutes of Sessions from the Indonesian Independence Preparatory Investigation Agency (BPUPKI) (29 May 1945 - 16 July 1945) and the Preparatory Committee for Indonesian Independence (PPKI) (18 and 19 August 1945) relating to the Compilation of the 1945 Constitution. Jakarta: State Secretariat of the Republic of Indonesia, [without year]).

Kahin, George McTurnan, Nationalism and Revolution in Indonesia. Kuala Lumpur: Language and Library Council of the Malaysian Ministry of Education, 1980.

Kahin, Audrey. Rebellion to Integration: West Sumatra and the Indonesian Polity, 1926-1998. Amsterdam: Amsterdam University Press, 1999.

, Audrey R. Regional Dynamics of the Indonesia Revolution: Unity from Diversity. Honolulu: University of Hawaii Press, 1985.

Khan, Rais A., et al. An Introduction to Political Science, revised edition. Georgetown, Ontario: IrwinDorsey Limited, 1977.

Kleden, Ignas. Pancasila, Ideology and Weltanschauung (paper). Delivered at the KWI Lay Apostolic

Commission Workshop on October 1, 2019 at Atmajya Catholic University, Jakarta.

Honorary Council Performance Report for the 2020 Election. Jakarta: DKPP RI, 2020.

Honorary Council Performance Report for the 2019 Election. Jakarta: DKPP RI, 2019. 
Laffan, Michael. History of Islam in the Archipelago. Yogyakarta: Bentang Pustaka, 2015.

Leeds, C. A., Political Studies, 2nd edition. London: MacDonnald \& Evans, Ltd., 1975.

Magnis-Suseno SJ, Franz. Seeking the Figure of Democracy: A Philosophical Study. Jakarta: PT Gramedia Pustaka Utama, 1995.

, Franz, "The Ideals of Bung Hatta State", paper in a national seminar on Dissecting Bung Hatta's Struggle Thought. National Archives of the Republic of Indonesia, 14 August 2002.

Maarif, Ahmad Syafii. Islam in the Frame of Indonesianness and Humanity: A Historical Reflection. Jakarta: Mizan, 2015.

Mazour, Anatole G. and John M. Peoples. Men and Nations: A World History, 3rd edition. New York: Harcourt Brace Jovanovich, 1975.

Meyer, Thomas. Democracy: An Introduction to Application. Jakarta: Friedrich-Ebert-Stiftung Indonesian Representative Office, 2005.

Nasution, Adnan Buyung. The Aspirations of Constitutional Government in Indonesia. Jakarta: Grafiti, 1995.

Panji Anugerah. Asian Democracy Index: The 2014 Case of Indonesia. Jakarta: Center for Political Studies (Puskapol) UI, 2014.

Profiles of Members of the House of Representatives and Members of the Regional Representative Council of the Republic of Indonesia for the period 2014 - 2019. Jakarta: General Election Commission, 2014.

Profiles of Members of the House of Representatives and Members of the Regional Representative Council of the Republic of Indonesia for the period 2019 - 2024. Jakarta: General Election Commission, 2019.

Rauf, Maswadi. Deliberation for Consensus: A Way of Determining Political Policy in Political Development in Indonesia. Jakarta: UIPress (no year ).

Minutes of the Session of the Investigating Committee for Preparatory Efforts for Indonesian Independence (BPUPKI) Preparatory Committee for Indonesian Independence (PPKI). Jakarta: State Secretariat of the Republic of Indonesia, 1995.

Silalahi, Harry Tjan. "Christian Cadres: Urgency and Challenges", in the Call to Build the Nation and the State. Basic Guidelines and Directions for Christian Political Involvement. Jakarta: PDKB Love for the Nation, 2009.

Soekarno. Under the Flag of the Revolution, Volume I. Jakarta: Publishing Committee under the Flag of the Revolution, 1964.

Soekarno. The philosophy of Pancasila according to Bung Karno. (editor Floriberta Aning). Yogyakarta: Media Pressindo, 2016.

----------. Indonesia Sues (Bung Karno's Defense Speech in front of Landraad Bandung 1930). Solo: Sasongko Publishing Agency, 1978.

Sulaeman. Moh Hatta's Democratic Thought, [dissertation]. Jakarta: Political Science UI, 2009.

Surjo, et al., Djoko. Religion and Social Change: Studies on the Relationship between Islam, Society, and Indonesian Socio-Political Structures. Yogyakarta: Center for Social and Southeast Asian Studies, UGM, 2001.

Zainuddin, A. R. Islamic Political Thought: Islam, Middle East and the Clash of Ideologies. Jakarta: Penerbit Pencil-324, 2004. 